\title{
The Media as a Window on the Past? The Impact of Television and Newspaper Consumption on Knowledge of the Democratic Transition in Portugal
}

\author{
José Santana-Pereira
}

To cite this article: José Santana-Pereira (2016): The Media as a Window on the Past? The Impact of Television and Newspaper Consumption on Knowledge of the Democratic Transition in Portugal, South European Society and Politics, DOI: 10.1080/13608746.2015.1131449

To link to this article: http://dx.doi.org/10.1080/13608746.2015.1131449

曲 Published online: 24 Mar 2016.

Submit your article to this journal $\square$

山 Article views: 40

View related articles

View Crossmark data $\nearrow$ 


\title{
The Media as a Window on the Past? The Impact of Television and Newspaper Consumption on Knowledge of the Democratic Transition in Portugal
}

\author{
José Santana-Pereira
}

\begin{abstract}
This study seeks to expand our understanding of how the media increase the level of political information, by focusing on an understudied yet important learning outcome: knowledge of the political past. The article explores the factors underlying variation in the recognition of the leading actors in the transitional process in Portugal. The results show that television news and newspaper exposure foster recognition of these actors, but that media use interacts with personal experience of the transition (stronger effects among younger cohorts) and party identification (stronger impact on those who do not feel close to a political party).
\end{abstract}

\section{KEYWORDS}

Political knowledge; media effects; democratic transition; political past; Portugal

The idea that a knowledgeable and well-informed citizenry is of paramount importance to the quality of democracy is one of the best-accepted assumptions in contemporary political science. Being informed about politics is regarded as a critical component of effective citizenship in democratic regimes, since people need information to evaluate leaders, parties, proposals and issues, and to know how to participate in the political process in the most effective way possible. As Galston (2001, p. 217) puts it, 'a well-ordered polity requires citizens with the appropriate knowledge, skills and traits of character'. While traits of character are beyond the intervention of political institutions, skills and knowledge can be acquired and encouraged by institutions aiming to facilitate the quality of the democratic process. Political knowledge helps people understand their interests both as individuals and as members of a group, improves the consistency of views across issues and across time, eases the understanding of political events and the digestion of new information, reduces the risk of alienation or mistrust in politics, promotes support for democratic values and fosters participation (Delli Carpini \& Keeter 1996; Galston 2001; De Vreese \& Boomgaarden 2006). In other words, political knowledge is key to achieving satisfactory results in terms of the quality of democracy.

Most studies of political knowledge focus on general or campaign- or election-specific information (Barabas et al. 2014), including civic facts that do not often change (e.g. the number of seats in the national parliament, the specifics of the electoral system) or concern current affairs (e.g. the name of the prime minister). By doing so, these studies neglect the 
importance of knowledge of other aspects of politics. Here it is argued that, in addition to knowledge of recent or stable current affairs, citizens should also have some knowledge of the country's political past.

This is based on the assumption that issue, party and leader appraisals should be dependent not only on what was said or done yesterday, but on actions over a longer timescale. Factual short-term political knowledge is important, but a longitudinal understanding of political processes among citizens could help improve the quality of democracy by undermining the current trend of short-term political action while making political parties and representatives more accountable. It is often said that voters have no memories; this belief transforms political communication into a short-term process that focuses on appraisals of the economic conditions, the most recent events and the current political leaders and candidates. However, the political process is as path dependent as any other kind of societal process. This is particularly so in the third-wave democracies, such as Portugal, where the current political consequences of the dictatorship and the transitional process are discussed by politicians and journalists, where most of the current political parties were formed or strengthened during the transitional years and where some of the leading figures during the transition to democracy remain politically important to this day. The same line of reasoning holds for other post-authoritarian and post-communist democracies in Europe and beyond.

Also, being knowledgeable of the political past is a necessary condition for the stability and meaningfulness of attitudes towards that past (Eagly \& Chaiken 1993). In the case of the Portuguese democratic transition, research has shown that there was a positive consensus around the outcomes of the Carnation Revolution and the process of democratic transition in both 2004 and 2014 (Lobo, Pinto \& Magalhães 2016); moreover, attitudes towards the transition shape the party identifications and ideological self-placements of the Portuguese (Lobo 2016), and are a key factor in people's satisfaction with democracy (Sanches \& Gorbunova 2016). Whether these attitudes are stable and have a lasting impact on other political attitudes may depend on how deeply rooted they are in knowledge of what happened in Portugal in 1974-76.

This article seeks to explore the dynamics of and factors of knowledge of the political past in a third-wave democracy in which that past is still politically relevant: Portugal. Political knowledge is therefore operationalised here as recognition of the main actors at a key moment in Portugal's political past, who played a significant role in the transition process of 1974-76: Melo Antunes, Vasco Gonçalves, Costa Gomes, Otelo Saraiva de Carvalho, António de Spínola, Freitas do Amaral, Ramalho Eanes, Álvaro Cunhal, Sá Carneiro and Mário Soares. Some of these figures were leaders of the main/new political parties that emerged following the revolution, while others were in the military and played an important part in the revolution and its aftermath through their involvement in the MFA (Movimento das Forças Armadas - Armed Forces Movement), their presence in the provisional governments or the JSN (Junta de Salvação Nacional - National Salvation Junta) or their role in the events of 25 November 1975 which ended the threat of a communist regime (Manuel 1996; Pinto 2011; Raimundo 2012).

The main aim of this article is to explore both the impact different kinds of media (newspapers and television) have on the recognition of these actors and the interaction between media use and variables usually associated with gaps in political knowledge: education and political interest (Delli Carpini \& Keeter 1996). These interactions are important because they shed light on whether media exposure is a way to increase or reduce gaps in 
political knowledge caused by structural or motivational factors. In other words, the goal is to observe whether the traditional models of political knowledge are useful to understanding the variation of a different type of political information, focused on the recent past. A second goal is to analyse the media contribution to the knowledge of an unobtrusive issue by testing the impact of media exposure among citizens with no direct experience of the transition and by analysing the variation in media effects according to the post-transitional visibility of individual actors. In this way, this article will contribute not only to the strand of research on knowledge and attitudes about the political past in third-wave democracies but also to the discussion of the positive and undesirable effects of exposure to political news in the media - a debate that is as classical as it is ongoing (Bartels 1993; Newton 2006).

The article is organised as follows. In the next section, we discuss existing literature on media and political knowledge and present our main hypotheses. We then describe the data and the results of a series of regression models. The article ends with a discussion of the main patterns observed and their implications.

\section{Media use and political knowledge: literature review and hypotheses for the study of learning about the political past}

Political knowledge can be defined as 'the range of factual information about politics that is stored in long-term memory' (Delli Carpini \& Keeter 1996, p. 10). According to these authors, the factors underlying political knowledge concern ability (whether someone has the cognitive skills to develop that knowledge), motivation (the desire to acquire political information) and opportunity (availability of political information). Using this framework, studies on political knowledge have focused on individual characteristics such as formal education (Tichenor, Donohue \& Olien 1970; Delli Carpini \& Keeter 1996), partisanship (Jerit \& Barabas 2012) or media exposure (Chaffee \& Kanihan 1997).

Formal education is correlated with political knowledge in the sense that better-educated citizens tend to be more knowledgeable (Tichenor, Donohue \& Olien 1970; Delli Carpini \& Keeter 1996). This relationship is so widely established that several studies have used education as a proxy for political knowledge or political sophistication (MacKuen 1984; Krause \& Granato 1998; Nicholson 2008; McAvoy 2015). While education is concerned with ability and opportunity, interest in politics is related to the motivation to obtain political information, and a key factor of political knowledge (Liu \& Eveland 2005). Party identification and ideological extremity can be regarded as proxies for political motivation, on the assumption that those who feel close to a political party tend to be more interested in politics than those who are not close to a political party (Bennett \& Bennett 1989), and that those who are more radical ideologically (that is, closer to the extreme right or the extreme left) may also display higher levels of motivation. Research has indeed shown that ideologically more extreme citizens tend also to be better informed (Palfrey \& Poole 1987).

In addition to education levels and involvement with politics, which provide citizens both the resources and the motivation to gather information about politics, the media are regarded as a crucial factor in the attainment of political knowledge. In the context of considerable academic scepticism of the role of the media in contemporary democracies (Newton 2006), a number of studies have reported knowledge gains associated with media use (Chaffee \& Schleuder 1986; Zhao \& Chaffee 1995; Chaffee \& Kanihan 1997; Norris \& Sanders 2003). For example, when examining a series of election campaigns during the $1980 \mathrm{~s}$ 
and 1990s, Zhao and Chaffee (1995) observed that, when demographic and political interest variables are controlled for, attention to political news on the television consistently results in greater knowledge of political issues. Other studies have also consistently found that media exposure has an impact on knowledge of candidate issue positions during elections (Weaver \& Drew 2001; Drew \& Weaver 2006). Recently, Tran (2013) observed that traditional media news consumption (television, radio and newspapers) provides a greater contribution to political knowledge than does new, internet-based, media use.

As De Vreese and Boomgaarden (2006) note, we ought to expect different kinds of media to have different effects on their audiences. The reasons for this expectation concern both media format and content. In terms of the former, the main distinction is between television and newspapers. A few studies suggest newspaper readers are better informed than television news watchers (Delli Carpini \& Keeter 1996) or that reading newspapers results in higher levels of political knowledge (Berkowitz \& Pritchard 1989; Druckman 2005). The differences between the educational potential of newspapers and television news are often explained by the different types of experience involved in consuming news via television and newspapers (different degrees of attention and skills), constraints in terms of the time and space inherent to the two media and the presence and nature of visual and audiovisual cues that can encourage or hinder learning effects (Graber 1990; Norris \& Sanders 2003). The type of knowledge fostered by television news and newspapers may also differ: the former improve knowledge of candidates and political actors - perhaps as a result of the television news's more personalised focus - while the latter improve knowledge of the policy differences between parties (Chaffee, Zhao \& Leshner 1994). As for content, De Vreese and Boomgaarden (2006) found knowledge gains as a consequence of exposure to media outlets rich in political news content, such as public broadcasters and quality newspapers in Denmark and the Netherlands. Likewise, in their experimental study of the media's impact on learning, Norris and Sanders (2003) noted that what makes the difference is 'not the structural features of textual versus audio-visual modes of transmission, but rather the type of journalism and the contents of the campaign news' (p. 233).

Here we focus on the distinction between newspapers and television news. The aim is to discover whether the differences between the two types of media outlets lead television viewers and newspaper readers to exhibit different levels of knowledge of the political past. Beyond the differences between audiovisual and print media in terms of format and user experience, there are also disparities between the content of newspapers and of television news in Portugal, which tend to favour the former (even though more in terms of the depth of analysis than in terms of accuracy) (Popescu et al. 2012). We therefore expect that:

Hypothesis 1: Televised news exposure will have a smaller impact in the recognition of past political actors than will newspaper exposure.

Undoubtedly, the media can only increase knowledge about a specific issue if it receives coverage in the newspapers, news broadcasts and other information programmes. In the case of Portugal, the odds of being exposed in the media to information about the 1974 Carnation Revolution and the subsequent democratic transition vary considerably, although there is a fairly stable cycle in the coverage of this issue, which peaks around 25 April, the anniversary of the revolution. In April 2014, the newspaper Público published 258 items on this issue, three times more than in March and twice as many times as in May. The coverage of this issue in another newspaper, Jornal de Notícias, mirrored this trend. The public television company RTP (Rádio e Televisão de Portugal - Radio and Television Portugal) broadcast a 
series of special programmes, documentaries and news reports on the subject while the commercial channels either broadcast special programmes in celebration or transmitted from revolutionary landmarks, such as the Carmo Barracks. Previous anniversaries, while receiving less coverage, were nevertheless addressed with special programmes dealing with the significance of the revolution and the democratic transition. The same trend tends to be visible on the anniversaries of other important events during the revolutionary period, such as the 25 November 1975 coup. To summarise, media users have many opportunities to find out about the revolution or to improve their knowledge of it.

Beyond the study of the main effects of media use on political knowledge, past research has focused on exploring the contribution of media exposure to the gap that exists between people of different socio-economic backgrounds. The knowledge gap hypothesis, which was first proposed during the early 1970s, claims that disparities in political knowledge information among different socio-economic groups are enhanced by the availability of information, since educated citizens are much better placed to use the political news media and to learn from it than are the less well educated (Tichenor, Donohue \& Olien 1970). This hypothesis has received considerable empirical support (Viswanath \& Finnegan 1996; Tran 2013).

However, it is reasonable to expect media use will have different impacts on the knowledge gap between the better- and less-well-educated segments of society according to the type of media. In fact, for the latter, watching televised political news improves knowledge to a greater extent than does reading newspapers, while for the highly educated reading political news in a newspaper is a more efficient way for them to improve their knowledge. In other words, newspapers widen the knowledge gap while television contributes to narrowing it (Kleinnijenhuis 1991; Viswanath \& Finnegan 1996; Kwak 1999; Eveland \& Scheufele 2000). This is due to the nature of the two formats, differences in target audiences (newspapers are often described as having a middle-class orientation compared with the more popular orientation of some televised news), audience motivation, the complexity of the information supplied, and the resources required to understand and digest it (Viswanath \& Finnegan 1996). Based on this, we expect that:

Hypothesis 2a: Exposure to televised political news will have a stronger impact among the less educated, thus contributing to narrowing the knowledge gap between education groups.

Hypothesis 2b: Exposure to political content in the newspapers will have a stronger impact for the better educated, thus contributing to widening the knowledge gap between education groups.

There are other structural and motivational factors whose impact on political knowledge may moderate the effect of exposure to political news in the media. For instance, should we expect the media to encourage knowledge among people who are very interested in politics (and who actively seek out such information) or those who are less interested but who may learn from it in a passive, incidental way (Krugman \& Hartley 1970; Graber 1990)? According to Chaffee and Frank (1996), both print and televised news produce knowledge, but while the former is used more often by people who are actively seeking information, the latter reaches and impacts on the less motivated groups, which include young people, immigrants and those who have no particular interest in politics. The hypotheses derived from this are: 
Hypothesis 3a: Exposure to televised political news will have a greater impact among those who are less interested in politics, thus contributing to narrowing the knowledge gap between groups with different degrees of motivation to follow politics.

Hypothesis 3b: Exposure to political content in the newspapers will have a greater impact for those who are very interested in politics, thus contributing to widening the knowledge gap between groups with different levels of interest in political subjects.

An additional factor that may interact with the frequency of media exposure is the nature of the issues about which citizens are expected to learn. For instance, the obtrusiveness of issues may play an important role. Simply put, an issue is obtrusive if the public has had direct experience with it, and unobtrusive if not (Zucker 1978): international affairs are more unobtrusive than domestic issues, while inflation is the quintessential obtrusive issue, since it impacts on everyone's life. For those fully socialised under the democratic regime, the transition and its protagonists are most likely unobtrusive. According to the 2011 census, around 47 per cent of the Portuguese population was born after 1971, and was therefore socialised under the democratic regime. Therefore, for almost half of all Portuguese citizens, the revolution and the transitional years may be as distant as other important dates in Portugal's twentieth-century political history. This may be exacerbated by the fact that this topic is not as politicised as similar experiences are in other post-authoritarian democracies (Raimundo 2012); also, these events are believed to have become ancient history, remembered only by selective memories, as early as the mid 1990s (Maxwell 1995). The impact of media use is believed to be stronger on perceptions of unfamiliar issues, issues that are complex or unclear, than on perceptions of issues that people experience directly (Newton 2006). In the same vein, issues that would not be identifiable if they had not received media coverage are those where media effects will be stronger (Dearing \& Rogers 1996); this is known as the 'obtrusive contingency hypothesis' (Lee 2004). Since in the case of the transition to democracy younger citizens have not had direct experience of this period, we expect the obtrusive contingency hypothesis to be correct: media effects will be strong among these respondents.

A second way of dealing with the unobtrusiveness of the issues surrounding the transition to democracy involves differentiating between the political actors who played a leading role during the revolutionary period of 1974-76. We expect the media effects to be striking in the case of personalities who either disappeared from the public sphere after the democratic consolidation or became less important in the political realm (e.g. Melo Antunes, Vasco Gonçalves, Costa Gomes, Otelo Saraiva de Carvalho, António de Spínola). In turn, the contribution of media exposure may be less significant in the case of those personalities who had a political or institutional role after the transition: Mário Soares (founder of the centre-left PS [Partido Socialista - Socialist Party], prime minister in 1976-78 and 1983-85, president of the Republic in 1986-96, member of the European Parliament (MEP) in 1999-2004 and presidential candidate in 2006), Sá Carneiro (founder of the centre-right PSD [Partido Social Democrata - Social Democratic Party] and prime minister in 1980), Álvaro Cunhal (leader of the Communist Party until 1992), Ramalho Eanes (president of the Republic in 1976-86) and Freitas do Amaral (founder of the right-wing CDS-PP [CDS-Partido Popular - CDS-Popular Party], its occasional leader up until the early 1990s and minister of foreign affairs in a PS government in 2005-06). We therefore expect that: 
Hypothesis 4a: The impact of media exposure will be more pronounced among those who were socialised after Portugal's transition to democracy.

Hypothesis 4b: The impact of the media will be more pronounced in the case of actors who did not have a leading political or institutional role after the transition.

\section{Data and variable operationalisation}

This article is based on data collected by the Quality of Democracy Barometer ${ }^{1}$ in 2014, which interviewed 1,254 residents of mainland Portugal aged 15 and over. The dependent, independent and control/moderator variables derived from this data-set are presented in Table 1. There are two groups of dependent variables: a general index of transitional actor recognition and nine dummies, one for each actor (Mário Soares, who was recognised by 99 per cent of the respondents, was excluded from the actor-focused analysis carried out to test Hypothesis $4 b$, since in his case there is no variation to be explained). In terms of independent variables, two indexes of exposure to political news on television and in newspapers were created, with a scale ranging from 'never' to 'everyday'. The respondents' gender, age and personal experience of the transition (whether socialised before or after the end of the democratic transition) are controlled for, as are their educational attainment, party identification and ideological extremity. The latter two variables are used as proxies for political interest.

Table 1. Variables used in the regression models.

\begin{tabular}{|c|c|c|}
\hline Variable & Question used (author's translation) & Final scale \\
\hline \multicolumn{3}{|l|}{ Dependent } \\
\hline Actor recognition index & $\begin{array}{l}\text { Now I am going to talk about some figures from } \\
\text { our recent history. Do you know who XXXX is? }\end{array}$ & $\begin{array}{l}0 \text { (doesn't know any of the ten } \\
\text { political actors) to } 10 \text { (knows all ten } \\
\text { political actors) }\end{array}$ \\
\hline $\begin{array}{l}\text { Recognition of individual } \\
\text { protagonists ( } 9 \text { different } \\
\text { dummies) }\end{array}$ & $\begin{array}{l}\text { Now I am going to talk about some figures from } \\
\text { our recent history. Do you know who XXXX is? }\end{array}$ & $\begin{array}{l}\text { Dummy: } 1=\text { respondent knows } \\
\text { who the political actor is }\end{array}$ \\
\hline \multicolumn{3}{|l|}{ Independent } \\
\hline $\begin{array}{l}\text { Exposure to political content } \\
\text { in newspapers }\end{array}$ & $\begin{array}{l}\text { How often do you read the politics section in the } \\
\text { newspaper? }\end{array}$ & $\begin{array}{l}\text { Five-point scale, from } 1 \text { (never) to } 5 \\
\text { (every day) }\end{array}$ \\
\hline $\begin{array}{l}\text { Exposure to political content } \\
\text { on TV }\end{array}$ & How often do you watch political news on TV? & $\begin{array}{l}\text { Five-point scale, from } 1 \text { (never) to } 5 \\
\text { (every day) }\end{array}$ \\
\hline \multicolumn{3}{|l|}{ Control/Moderator } \\
\hline Education & What is your highest level of education? & $\begin{array}{l}6 \text { categories: } 1 \text { (less than } \\
\text { elementary; } 4 \text { th grade) to } 6 \\
\text { (university-level; BA, MA, PhD) }\end{array}$ \\
\hline Party identification & $\begin{array}{l}\text { Considering the Portuguese political parties, do } \\
\text { you feel close to any of them? }\end{array}$ & $\begin{array}{l}\text { Dummy: } 1=\text { respondent feels close } \\
\text { to a party }\end{array}$ \\
\hline Ideological extremity & $\begin{array}{l}\text { Based on your political views, how would you } \\
\text { place yourself on a scale from } 1 \text { to } 10 \text {, on which } 1 \\
\text { represents the most left-wing position and } 10 \text { the } \\
\text { most right-wing position? }\end{array}$ & $\begin{array}{l}\text { Dummy: } 1 \text { = respondent is either } \\
\text { extreme left-wing }(1-3) \text { or extreme } \\
\text { right-wing }(8-10)\end{array}$ \\
\hline $\begin{array}{l}\text { Personal experience of } \\
\text { transition }\end{array}$ & How old are you? & $\begin{array}{l}\text { Dummy: } 1=\text { respondent was } \\
\text { socialised (i.e. entered school) after } \\
\text { the transition had ended }\end{array}$ \\
\hline Gender & Registered by interviewer & Dummy: $1=$ female \\
\hline Age & How old are you? & Continuous \\
\hline
\end{tabular}




\section{Results}

On average, the 2014 Quality of Democracy Barometer survey respondents recognise 7.6 of the ten political personalities who played a leading role during the transition: however, levels of recognition vary considerably (the standard deviation is of 2.3). The regression models presented in Table 2 take a general index of recognition, on a $0-10$ scale, as the dependent variable, and aim to explain some of that variation. Model 1 tests the main effects: that is, the impact of newspaper and television consumption on the recognition of transitional actors after controlling for gender, education, political interest (measured through such proxies as party identification and ideological extremity), age and personal experience of the transition. In turn, in order to analyse whether media use for political news increases or reduces knowledge gaps due to ability or motivation, Models $2-5$ test the interaction effects between media-related variables and some of the factors mentioned above.

In Model 1, exposure to political news both in the newspapers and on television has a positive impact for transitional actor recognition (Table 2). In the case of newspapers, when other factors are held at their mean values, those who never read the news recognise on average 7.7 actors, while those who read newspapers every day recognise 8.3 actors on average. The magnitude of the television effect is similar: while those who do not watch the news know 7.5 political figures, the recognition rate among those who follow the political news on television each day is 8.1. This means that the differences between television and newspaper impacts postulated in Hypothesis 1 are not observed: the two media seem to be equally able to promote knowledge of the political past.

Education and party identification have a positive impact on the recognition of past political protagonists, and there is a significant gender gap (when everything is controlled for, women recognise fewer names than men) and a generation gap, those born after 1970 recognising fewer transitional actors. Ideological extremity has no measurable impact on recognition rates (Table 2 ).

Models 2 to 5 were designed to test hypotheses concerning the interaction between media use and other factors of political knowledge - education, party identification and ideological extremity - as well as the hypothesis positing that media effects will be stronger among those who were socialised after the transition. Each model includes the same set of variables tested in Model 1 and two interaction terms between the variable of interest and the indexes of newspaper and television use for political news. The most striking result is that media use does not have a distinct effect for the less and the more educated (Table 2; Model 3). The impact of newspaper and televised news consumption is therefore fairly equal across education groups. This means there is no empirical support for hypotheses $2 \mathrm{a}$ and $2 \mathrm{~b}$.

Model 4 shows a significant interaction between party identification and television news consumption. In fact, watching political news on the television only has an effect among those who do not feel close to a political party: when other factors are held constant, recognition rates go from 7.1 among those who do not watch the news to 8.1 among those who watch the television news each day (Figure 1). Watching the television for political news is not associated with the recognition of transitional actors index among those who feel close to a political party. Interestingly, exposure to television causes the gap between those who are more engaged politically and the disaffected to disappear. While among non-viewers the difference between respondents with and without party attachments is significant (those who feel close to a party being more knowledgeable), it becomes statistically irrelevant 
Table 2. Media impact on recognition of political actors during the transition to democracy: OLS (ordinary least squares) regressions.

\begin{tabular}{|c|c|c|c|c|c|}
\hline & Model 1 & Model 2 & Model 3 & Model 4 & Model 5 \\
\hline Intercept & $\begin{array}{l}4.67 * * * \\
(0.47)\end{array}$ & $\begin{array}{l}4.95^{* * * *} \\
(0.51)\end{array}$ & $\begin{array}{l}5.48^{* * * *} \\
(0.64)\end{array}$ & $\begin{array}{l}4.40^{* * * *} \\
(0.50)\end{array}$ & $\begin{array}{l}4.62^{* * * *} \\
(0.48)\end{array}$ \\
\hline Gender (female) & $\begin{array}{c}-0.52^{* * *} \\
(0.12)\end{array}$ & $\begin{array}{c}-0.53^{* * *} \\
(0.12)\end{array}$ & $\begin{array}{c}-0.51^{* * * *} \\
(0.12)\end{array}$ & $\begin{array}{c}-0.51^{* * *} \\
(0.12)\end{array}$ & $\begin{array}{c}-0.50^{* * * *} \\
(0.12)\end{array}$ \\
\hline Age & $\begin{array}{l}0.05^{* * * *} \\
(0.01)\end{array}$ & $\begin{array}{l}0.04^{* * * *} \\
(0.01)\end{array}$ & $\begin{array}{l}0.05^{* * * *} \\
(0.01)\end{array}$ & $\begin{array}{l}0.05^{* * * *} \\
(0.01)\end{array}$ & $\begin{array}{l}0.05^{* * *} \\
(0.01)\end{array}$ \\
\hline Socialised after 1976 (yes) & $\begin{array}{c}-0.85^{* * *} \\
(0.22)\end{array}$ & $\begin{array}{c}-1.27^{* * *} \\
(0.38)\end{array}$ & $\begin{array}{c}-0.82^{* * *} \\
(0.22)\end{array}$ & $\begin{array}{c}-0.83^{* * *} \\
(0.22)\end{array}$ & $\begin{array}{c}-0.80^{* * *} \\
(0.22)\end{array}$ \\
\hline Education & $\begin{array}{l}0.28^{* * *} \\
(0.06)\end{array}$ & $\begin{array}{l}0.28^{* * * *} \\
(0.06)\end{array}$ & $\begin{array}{c}-0.02 \\
(0.15)\end{array}$ & $\begin{array}{l}0.28^{* * * *} \\
(0.06)\end{array}$ & $\begin{array}{l}0.27^{* * * *} \\
(0.06)\end{array}$ \\
\hline Party identification (yes) & $\begin{array}{l}0.26^{*} \\
(0.13)\end{array}$ & $\begin{array}{c}0.26^{*} \\
(0.13)\end{array}$ & $\begin{array}{c}0.22 \\
(0.13)\end{array}$ & $\begin{array}{l}0.70^{*} \\
(0.33)\end{array}$ & $\begin{array}{l}0.24^{*} \\
(0.13)\end{array}$ \\
\hline Ideological extremity (yes) & $\begin{array}{c}0.03 \\
(0.13)\end{array}$ & $\begin{array}{c}0.03 \\
(0.13)\end{array}$ & $\begin{array}{c}0.09 \\
(0.13)\end{array}$ & $\begin{array}{c}0.04 \\
(0.13)\end{array}$ & $\begin{array}{c}-0.04 \\
(0.35)\end{array}$ \\
\hline Newspapers & $\begin{array}{l}0.12^{*} \\
(0.05)\end{array}$ & $\begin{array}{c}0.02 \\
(0.06)\end{array}$ & $\begin{array}{c}0.01 \\
(0.13)\end{array}$ & $\begin{array}{c}0.04 \\
(0.08)\end{array}$ & $\begin{array}{l}0.16^{* *} \\
(0.06)\end{array}$ \\
\hline TV & $\begin{array}{l}0.13^{* *} \\
(0.04)\end{array}$ & $\begin{array}{l}0.14^{*} \\
(0.06)\end{array}$ & $\begin{array}{c}-0.01 \\
(0.11)\end{array}$ & $\begin{array}{l}0.25^{* * * *} \\
(0.07)\end{array}$ & $\begin{array}{l}0.11^{*} \\
(0.05)\end{array}$ \\
\hline Socialised*Newspapers & & $\begin{array}{l}0.23^{*} \\
(0.09)\end{array}$ & & & \\
\hline Socialised*TV & & $\begin{array}{c}-0.03 \\
(0.08)\end{array}$ & & & \\
\hline Education*Newspapers & & & $\begin{array}{c}0.04 \\
(0.04)\end{array}$ & & \\
\hline Education*TV & & & $\begin{array}{c}0.05 \\
(0.04)\end{array}$ & & \\
\hline PartyID*Newspapers & & & & $\begin{array}{c}0.16 \\
(0.19)\end{array}$ & \\
\hline PartyID*TV & & & & $\begin{array}{c}-0.21 * \\
(0.09)\end{array}$ & \\
\hline Extremity*Newspapers & & & & & $\begin{array}{c}-0.08 \\
(0.10)\end{array}$ \\
\hline Extremity*TV & & & & & $\begin{array}{c}0.07 \\
(0.09)\end{array}$ \\
\hline $\mathrm{N}$ & & & 849 & & \\
\hline$R^{2}$ & $31.6 \%$ & $32 \%$ & $32.3 \%$ & $32.2 \%$ & $32 \%$ \\
\hline
\end{tabular}

Source: Author's elaboration of data collected by the Quality of Democracy Barometer Survey on the 40th Anniversary of the Carnation Revolution.

Notes: Values are unstandardised coefficients, with standard errors within parentheses. Multicollinearity diagnostics give negative results: except for interaction terms, no variance inflation factors (VIFs) higher than 3 . Values in bold are those that reach statistical significance with at least a 95\% confidence level. ${ }^{* *} p<0.001 ;{ }^{* *} p<0.01 ;{ }^{*} p<0.05$.

as the frequency of television news consumption increases and vanishes among those who watch political news each day (Figure 1). In Model 5 there is no statistically significant interaction between media use and ideological extremity. This means Hypothesis $3 a$ is (partially) supported by the data: the effect of viewing television is stronger among those who are least engaged with politics. Newspaper readership having no distinct impact on the politically engaged and disengaged, Hypothesis $3 \mathrm{~b}$ is not confirmed.

What about the impact of the personal experience of the transition? Model 2 in Table 2 shows that the interaction term between newspaper use and the dummy distinguishing between those born before and after 1970 is statistically significant. Figure 2 displays the predicted values of the recognition of transitional actors index (with 95 per cent confidence intervals) for these respondents according to their reported newspaper reading habits while holding all other variables constant. It shows that for the younger respondents there is a 


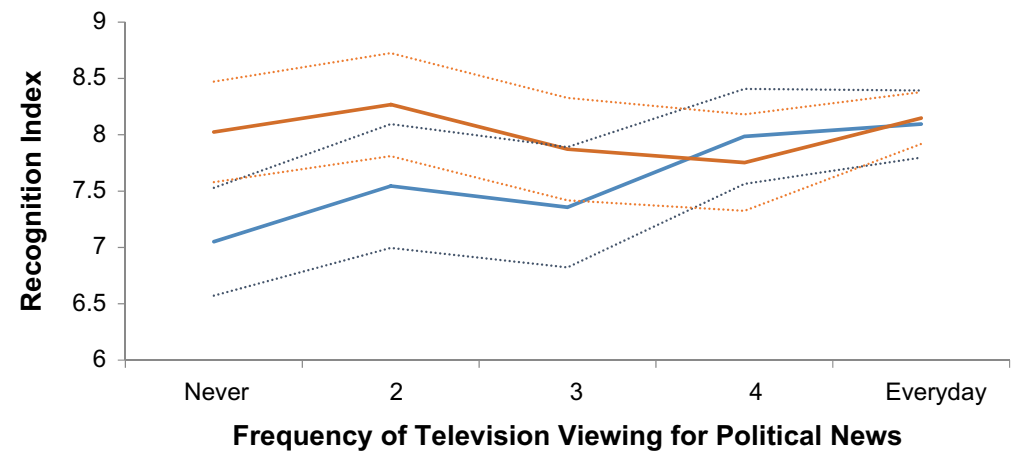

No Party ID —Party ID

Figure 1. Predicted values (with 95 per cent confidence intervals) for the recognition of transitional actors index according to the respondents' television news viewing habits and party identification.

Source: Author's elaboration of the data collected by the Quality of Democracy Barometer Survey on the 40th Anniversary of the Carnation Revolution.

Note: Confidence intervals are represented by dotted lines.

linear and positive relationship between newspaper readership and knowledge: those who never read newspapers recognise 7.1 political actors while those who read newspapers each day claim to recognise 7.9. In the case of the older respondents, the impact of newspaper use is not linear and the slope is much more modest, providing support for the idea that media effects are stronger for those with no direct experience of the transition period. Moreover, it seems newspaper reading contributes to a narrowing of the generation gap: while significant differences between younger and older respondents are observable among those who never read newspapers or do so less than once a week (levels 1 and 2 on the $x$-axis), they disappear when the frequency of newspaper reading is moderate to high. Since the interaction between television news exposure and personal experience is not statistically significant, Hypothesis $4 a$ is therefore only partially confirmed.

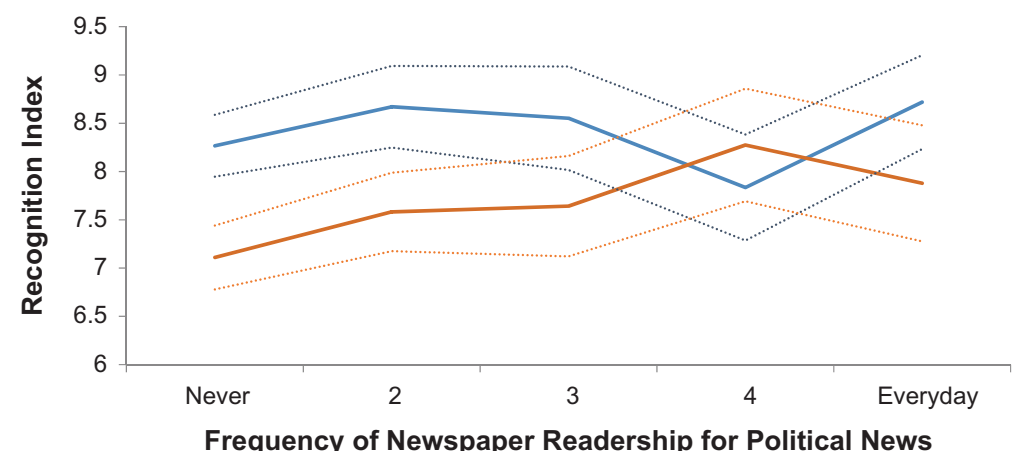

Frequency of Newspaper Readership for Political News

— Socialised before 1976 _ Socialised after 1976

Figure 2. Predicted values (with 95 per cent confidence intervals) for the recognition of transitional actors index according to the respondents' newspaper readership habits and personal experience of the transition. Source: Author's elaboration of the data collected by the Quality of Democracy Barometer Survey on the 40th Anniversary of the Carnation Revolution. Note: Confidence intervals are represented by dotted lines. 


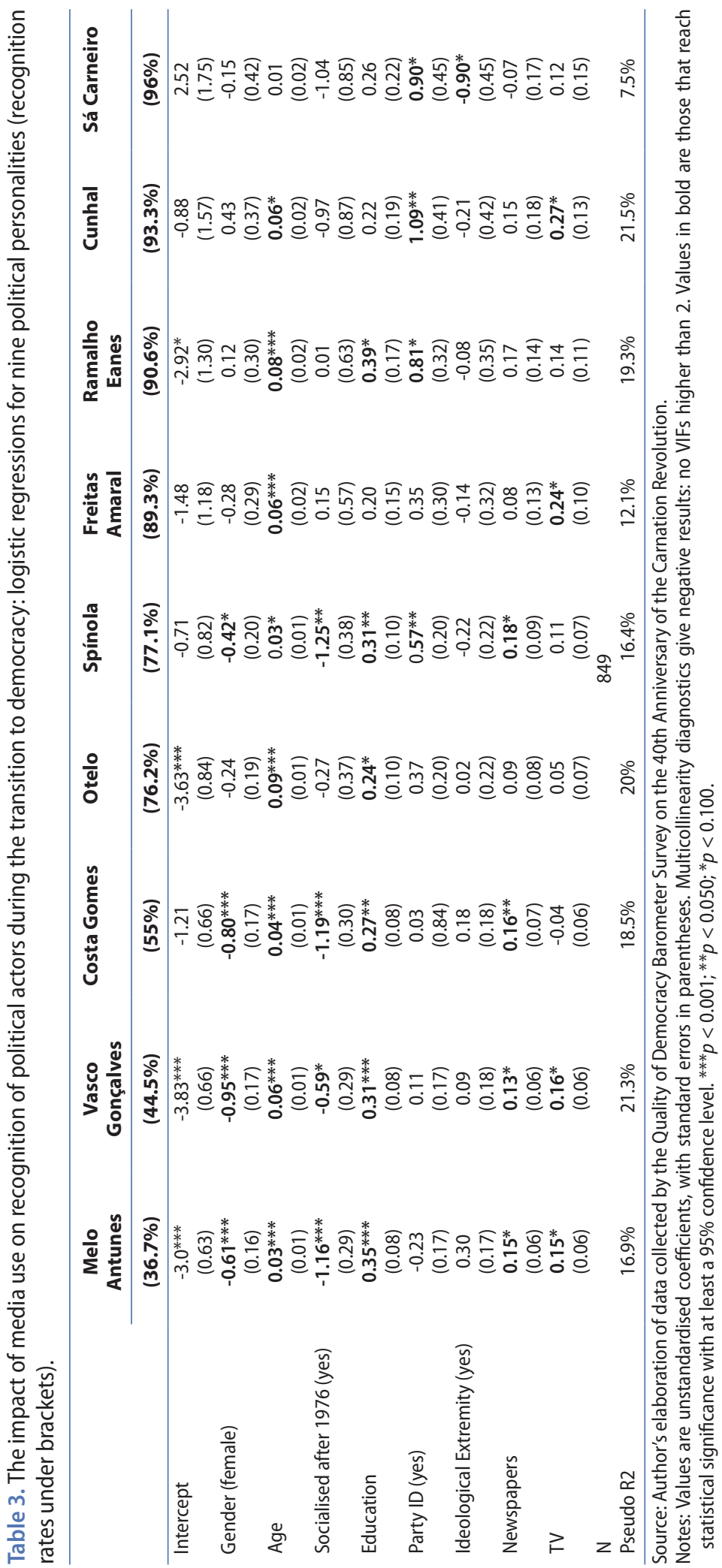


The personalities under analysis are considerably different in terms of background, actions, and impact on current political affairs in Portugal (some are dead, some have vanished from the political scene while others are seen by some as informal senators of the Portuguese democracy). Therefore, Hypothesis $4 \mathrm{~b}$ postulated that the media impact would vary according to the post-transitional role of this figures, being stronger for those who are transitional actors stricto sensu and had no leading political or institutional role after the transition. Table 3 presents the results of a series of logistic regressions designed to test this hypothesis by using the recognition of individual actors as outcomes. These logistic regressions, which use dummies ( $1=$ respondent knows who this person is) as dependent variables, are calculated for all actors except Mário Soares, who, as explained above, was recognised by 99 per cent of respondents - virtually everyone. The regression models in Table 3 are ordered from the least well-known actor (Melo Antunes, recognised by around 37 per cent of the respondents) to the most well-known (Sá Carneiro, recognised by 96 per cent). Individual recognition rates are presented below the name of each transitional actor.

The impact of media use is relevant in six of the nine regressions, the direction of the relationship confirming our expectations: greater exposure to political content in the media leads to a greater probability of recognising most of the political actors of the democratic transition (Table 3). There are, however, interesting differences between newspapers and television news. On the one hand, the frequency of televised political news viewing is associated with the ability to recognise two among the least well-known actors (Melo Antunes and Vasco Gonçalves, two military figures who left the political scene soon after the transition) and two of the most recognisable actors (the communist leader Álvaro Cunhal and one of the founders of the right-wing CDS-PP, Freitas do Amaral). On the other hand, the impact of newspaper readership is only observed in the cases of more unobtrusive transition protagonists: the two military men named above and the first two (appointed) presidents of the Portuguese republic following the Carnation Revolution (Generals Costa Gomes and Spínola). This means that Hypothesis $4 b$, which predicted stronger media effects in the case of the least visible actors, is only partially supported, since in fact this only occurs when the medium under analysis is the newspapers.

\section{Conclusions}

After four decades of democracy, some of the protagonists of the Carnation Revolution and the transition period that followed are not easily recognised by some segments of the Portuguese population. The aim of this article was to explore the factors underlying variations in knowledge about the political past, particularly about the military and political leaders who were of paramount importance during the transition to democracy. The relevance of this study to understanding the dynamics surrounding attitudes towards the past in young democracies stems from the assumption that knowledge of these leaders, taken as a proxy of knowledge of the events surrounding the transition to democracy in Portugal, may lead to more stable and meaningful attitudes towards the past, which are important factors of attitudes towards the current political arrangements (Lobo 2016; Sanches \& Gorbunova 2016).

The empirical analysis has shown that the levels of transitional actors recognition depend on ability and motivation factors such as education and interest in politics (here measured through the proxy of feeling close to a political party); however, media use, which constitutes 
a form of opportunity to acquire knowledge, also increases the probability of recognising these actors. While the scale of the effect of reading political news in the newspapers and watching television news broadcasts seems to be equivalent, it should be noted that television is more important in the case of those who do not feel attached to a political party, whom we assume to be less interested in politics (Bennett \& Bennett 1989). These results are consistent with Chaffee and Frank (1996) and with the idea of passive or incidental learning from the televised news even when the viewer has no real interest in politics (Graber 1990). Viewing television news contributes to narrowing the gap in the levels of political knowledge - in this case about the political past - between people who actively seek information about politics and those who are less motivated to do so.

A second positive outcome of consumption of political news is the fact that it enhances knowledge of the political past among those who, for reasons connected to their date of birth, did not experience the events in Portugal between 1974 and 1976. In fact, the more often the younger cohorts read about politics in the newspapers, the more they are able to recognise past political figures, independently of their education levels or political attachments. This means newspaper readership contributes to knowledge about leading actors during a phase of Portuguese history that is necessarily unobtrusive to those currently under the age of 45 . Moreover, the actor-focused empirical analysis shows that the impact of newspapers is mainly observed in relation to less well-known actors, most of whom are military figures who withdrew from the political scene shortly after the end of the transition period. As regards the impact of newspaper reading, the obtrusive contingency hypothesis is therefore confirmed (Lee 2004). Unfortunately, Portugal is, like several other Southern, Central and Eastern European democracies, a context where newspaper-reading habits are quite weak, and in which newspaper circulation figures suggest that the printed media are catering for a small segment of the population (Santana-Pereira 2015). This means that the benefits of newspaper reading in terms of knowledge of unobtrusive issues are restricted to the small group of citizens who actually read newspapers more than just occasionally.

In sum, by fostering knowledge of the democratic transition actors amongst those who are not very interested in politics and were not old enough to experience the 1974-76 events, both television news and newspapers may contribute to the development of stronger attitudes towards the Carnation Revolution and the transitional process that followed among the younger and less politically engaged segments of the Portuguese population.

These findings have clear policy implications. On the one hand, a flow of quality information on relevant (present and past) issues through television news should be fostered by political institutions interested in raising the quality of the democratic process, namely via public broadcasting, but without changing the televised newscasts' appealing format and language that catches the attention of disengaged or disinterested citizens. On the other, in a context in which newspapers cater for a small slice of the population, political institutions should promote newspaper reading in order to foster knowledge gain and the formation of attitudes on unobtrusive yet critical issues. Since the advent of free newspapers and newspaper websites has diluted, to a certain extent, the economic costs of newspaper consumption, the promotion of newspaper use should focus on developing reading habits, namely through institutional agents of socialisation (schools, universities, clubs).

While these results clearly indicate the importance of exposure to political information through the media in terms of knowledge of unobtrusive political issues such as the actors in 
the democratic transition of the mid-1970s, future research should focus on disentangling the effects of the media from other information-seeking behaviours that the observational data used in this article could not control for. Experimental research on these matters would be warmly welcomed. Also, the results regarding television were exclusively observed through the analysis of data on exposure to political news. There are other genres that may foster political knowledge of the past, although incidentally: fictional series depicting the last years of the dictatorship and the transitional process (for instance, Conta-me Como Foi and E Depois do Adeus, broadcast by RTP in the last decade) or movies about those issues seen on TV (for instance, Capitães de Abril). While currently there are no data available to test the effects of exposure to this kind of programming in Portugal, future research should also pursue this avenue of research.

\section{Note}

1. The Quality of Democracy Barometer (http://www.bqd.ics.ul.pt/) is a research structure based at the Institute of the Social Sciences, University of Lisbon, since 2010. The 2014 survey, aimed to measure political attitudes and satisfaction with democracy during the fortieth anniversary of the Carnation Revolution, was conducted by GfK Metris among a representative sample of the population aged 15 or over residing in Portugal. Respondents were selected using the quota method, based on a matrix that crosses the variables Sex, Age, Education, Occupation, Region, and Habitat/Settlement. The information was collected through direct personal interviews. The data are available upon request sent to Ms. Gorbunova ( ekaterina. gorbunova@ics.ul.pt).

\section{Acknowledgments}

The author would like to thank the anonymous referees for their suggestions, as well as Goffredo Adinolfi and Pedro Magalhães for their comments when an earlier version of this paper was discussed at a meeting of the ICS's social and political attitudes research group. Any shortcomings and remaining mistakes are exclusively the author's responsibility.

\section{Disclosure statement}

No potential conflict of interest was reported by the author.

\section{Notes on contributor}

José Santana-Pereira, PhD in political and social sciences (European University Institute, Florence, 2012), is a postdoctoral research fellow at the Institute of Social Sciences (ICS), University of Lisbon. His research interests comprise elections, public opinion, political attitudes and behaviour, media and politics and the organisation and effects of political campaigns. His work has been published in journals such as Electoral Studies and South European Society and Politics.

\section{References}

Barabas, J., Jerit, J., Pollock, W. \& Rainey, C. (2014) 'The question(s) of political knowledge', American Political Science Review, vol. 108, no. 4, pp. 840-855.

Bartels, L. M. (1993) 'Messages received: the political impact of media exposure', The American Political Science Review, vol. 87, no. 2, pp. 267-285. 
Bennett, L. L. M. \& Bennett, S. E. (1989) 'Enduring gender differences in political interest: the impact of socialisation and political dispositions', American Politics Research, vol. 17, no. 1, pp. 105-122.

Berkowitz, D. \& Pritchard, D. (1989) 'Political knowledge and communication resources', Journalism \& Mass Communication Quarterly, vol. 66, pp. 697-701.

Chaffee, S. H. \& Frank, S. (1996) 'How Americans get political information: print vs. broadcast news', The Annals of The American Academy of Political and Social Science, vol. 546, no. 1, pp. 48-58.

Chaffee, S. H. \& Kanihan, S. F. (1997) 'Learning about politics from the mass media', Political Communication, vol. 14 , no. 4, pp. 421-430.

Chaffee, S. H. \& Schleuder, J. (1986) 'Measurement and effects of attention to media news', Human Communication Research, vol. 13, no. 1, pp. 76-107.

Chaffee, S. H., Zhao, X. \& Leshner, G. (1994). 'Political knowledge and the campaign media of 1992', Communication Research, vol. 21, no. 3, pp. 305-324.

de Vreese, C. H. \& Boomgaarden, H. (2006) 'News, political knowledge and participation: the differential effects of news media exposure on political knowledge and participation', Acta Politica, vol. 41, pp. 317-341.

Dearing, J. W. \& Rogers, E. M. (1996) Agenda Setting, Sage, Thousand Oaks (CA).

Delli Carpini, M. X. \& Keeter, S. (1996) What Americans Know About Politics and Why it Matters, Yale University Press, Yale.

Drew, D. \& Weaver, D. (2006) 'Voter learning in 2004 election: did the media matter?', Journalism and Mass Communication Quarterly, vol. 83, no. 1, pp. 25-42.

Druckman, J. N. (2005) 'Media matter: how newspapers and television news cover campaigns and influence voters', Political Communication, vol. 22, no. 4, pp. 463-481.

Eagly, A. H. \& Chaiken, S. (1993) The Psychology of Attitudes, Harcourt Brace Jovanovich College Publishers, Orlando (FL).

Eveland, W. P. \& Scheufele, D. A. (2000) 'Connecting news media use with gaps in knowledge and participation', Political Communication, vol. 17, no. 3, pp. 215-237.

Galston, W. A. (2001) 'Political knowledge political engagement, and civic education', Annual Review of Political Science, vol. 4, pp. 217-234.

Graber, D. (1990) 'Seeing is remembering: how visuals contribute to learning from television news', Journal of Communication, vol. 40, pp. 134-156.

Jerit, J. \& Barabas, J. (2012) 'Partisan perceptual bias and the information environment', The Journal of Politics, vol. 74, no. 3, pp. 672-684.

Kleinnijenhuis, J. (1991) 'Newspaper complexity and the knowledge gap', European Journal of Communication, vol. 6, no. 4, pp. 499-522.

Krause, G. A. \& Granato, J. (1998)'Fooling some of the public some of the time? A test for weak rationality with heterogeneous information levels', Public Opinion Quarterly, vol. 62, pp. 135-151.

Krugman, H. E. \& Hartley, E. L. (1970) 'Passive learning from television', Public Opinion Quarterly, vol. 34, no. 2, pp. 184-190.

Kwak, N. (1999) 'Revisiting the knowledge gap hypothesis: education, motivation, and media use', Communication Research, vol. 26, no. 4, pp. 385-413.

Lee, G. (2004) 'Reconciling "cognitive priming" vs. obtrusive contingency hypothesis: an analytical model of media agenda-setting effects', Gazette: The International Journal for Communication Studies, vol. 66, no. 2, pp. 151-166.

Liu, Y.-I.- \& Eveland, W. P. Jr. (2005) 'Education, need for cognition, and campaign interest as moderators of news effects on political knowledge: an analysis of the knowledge gap', Journalism \& Mass Communication Quarterly, vol. 82, no. 4, pp. 910-929.

Lobo, M. C., Pinto, A. C., \& Magalhães, P. (2016) 'Portuguese democratisation 40 years on: its meaning and enduring legacies', South European Society and Politics, vol. 21, no. 2, pp. 163-180.

Lobo, M. C. (2016) 'Bringing the past back in: how attitudes towards the democratic transition influence the Portuguese voter', South European Society and Politics, vol. 21, no. 2, pp. 181-196.

MacKuen, M. (1984) 'Exposure to information, belief integration, and individual responsiveness to agenda change', The American Political Science Review, vol. 78, no. 2, pp. 372-391.

Manuel, P. C. (1996) The Challenges of Democratic Consolidation in Portugal: Political, Economic, and Military Issues 1976-1991, Praeger, Westport (CT). 
Maxwell, K. (1995) The making of Portuguese democracy, Cambridge University Press, Cambridge.

McAvoy, G. E. (2015) Collective political rationality: partisan thinking and why it's not all bad, Routledge, New York, NY.

Newton, K. (2006) 'May the weak force be with you: the power of the mass media in modern politics', European Journal of Political Research, vol. 45, no. 2, pp. 209-234.

Nicholson, S. P. (2008) 'Direct democracy and the public agenda: ballot initiatives and public beliefs about important problems' in Direct Democracy's Impact on American Political Institutions, eds S. Bowler \& A. Glazer, Palgrave, New York, pp. 55-68.

Norris, P. \& Sanders, D. (2003) 'Message or medium? campaign learning during the 2001 British general election', Political Communication, vol. 20, pp. 233-262.

Palfrey, T. R. \& Poole, K.T. (1987) 'The relationship between information, ideology and voting behaviour', American Journal of Political Science, vol. 31, no. 3, pp. 511-530.

Pinto, A. C. (2011) 'Twentieth century Portugal: an introduction', in Contemporary Portugal, ed A. C. Pinto, 2nd ed. Columbia University Press, NewYork, pp. 1-54.

Popescu M., Toka, G., Gosselin, T. \& Santana-Pereira, J. (2012) 'European media systems survey 2010: results and documentation', in Research report, Department of Government, University of Essex, Colchester. URL: www.mediasystemsineurope.org.

Raimundo, F. (2012) Post-Transitional Justice? Spain, Poland, and Portugal compared, Unpublished PhD Dissertation for the European University Institute, Florence.

Sanches, E. R. \& Gorbunova, E. (2016) 'Portuguese citizens' support for democracy: 40 years after the Carnation Revolution', South European Society and Politics, vol. 21, no. 2, pp. 211-226.

Santana-Pereira, J. (2015) 'Variety of media systems in third-wave democracies' in Media and Politics in New Democracies, ed. J. Zielonka, Oxford University Press, Oxford, pp. 231-247.

Tichenor, P. J., Donohue, G. A. \& Olien, C. N. (1970) 'Mass media flow and differential growth in knowledge', Public Opinion Quarterly, vol. 34, no. 2, pp. 159-170.

Tran, H. (2013) 'Does exposure to online media matter?' The knowledge gap and the mediating role of news use', International Journal of Communication, vol. 7, pp. 831-852.

Viswanath, K. \& Finnegan, J. R. Jr. (1996) 'The knowledge gap hypothesis: twenty-five years later', in Communication Yearbook 19, ed. B. R. Burleson, Sage, Thousand Oaks (CA), pp. 187-227.

Weaver, D. \& Drew, D. (2001)'Voter learning and interest in the 2000 presidential election: did the media matter?', Journalism and Mass Communication Quarterly, vol. 78, no. 4, pp. 787-798.

Zhao, X. \& Chaffee, S. H. (1995) 'Campaign advertisements versus television news as sources of political issue information', Public Opinion Quarterly, vol. 59, no. 1, pp. 41-65.

Zucker, H. G. (1978) 'The variable nature of news media influence', in Communication Yearbook 2, ed B. Ruben, Transaction Books, New Brunswick (NJ), pp. 154-172. 